\title{
MEDBORGARNAS MISSTRO TILL MASSMEDIAS RAPPORTERING AV POLITISKA SKANDALER
}

Tobias Bromander, Institutionen för statsvetenskap, Linnéuniversitetet E-post I tobias.bromander@lnu.se

Under de senaste 20 åren har en mängd politiska skandaler kommit och gått i Sverige. Under samma period har också mediedebatter om politiska skandaler har kommit och gått. I efterdyningarna av stora skandaler är det ofta två frågor som tar plats på dagordningen. För det första diskuteras hur massmedia väljer att gestalta politiker i allmänhet. Ger massmedia en rättvis beskrivning av politiker i skandaler? För det andra diskuteras ofta förekomsten av en eventuell könsdimension i mediernas gestaltning av skandaler. Granskas kvinnor och män olika hårt av massmedia? Dessa två frågor, som ofta diskuteras och debatteras, studeras genom frågeundersökningen Survey 2012. Syftet med denna artikel är att undersöka hur medborgarna uppfattar massmedias nyhetsrapportering om politiska skandaler.

(C) 2014 Tobias Bromander. Detta är en Open Access artikel distribuerad under CC-BY-NC som innebär att du tillåter andra att använda, sprida, göra om, modifiera och bygga vidare på ditt verk, men inte att verket används i kommersiella sammanhang. 
Finns det en tilltro till nyhetsrapporteringens innehåll eller finns det en misstro mot gestaltningen av politiker i skandaler? Dessa frågor kommer att besvaras i denna artikel. Frågorna har omformulerats till påståenden som respondenterna av Survey 2012 ombetts att ta ställning till (för detaljerad information om Survey 2012, se Hagevi 2014).

1. Massmedia ger ofta en orättvis beskrivning av politiker som hamnar i skandaler

2. Kvinnor granskas hårdare än män i politiska skandaler

Det första påståendet innehåller en neutral könsformulering och avser att fånga respondenternas allmänna uppfattning om massmedias gestaltning av politiska skandaler.

Det andra påståendet innehåller en genusmarkering och avser att fånga respondenternas attityder till en eventuell ojämlik nyhetsrapportering. Respondenterna gavs fem svarsalternativ till vardera påstående. Dessa var instämmer helt, instämmer delvis, varken eller, instämmer i stort sett inte och instämmer inte alls.

Påståendena analyseras i fyra olika steg. Detta görs för att kunna påvisa eventuella skillnader bland olika grupper av respondenter. I ett första steg analyseras datamaterialet utifrån respondenternas kön för att ta reda på om kvinnor och män har samma uppfattningar i frågan. I ett andra steg undersöks sambandet mellan ålder och inställning till massmedia. I ett tredje steg undersöks i vilken utsträckning respondenternas intresse för politik har betydelse för hur människors uppfattar nyhetsrapporteringen. I det fjärde och sista steget analyseras i vilken mån respondenternas subjektiva placering på en politisk vänster-högerskala har betydelse för inställningen till massmedias rapportering av politiska skandaler.

Analysen av undersökningsresultaten vilar på två grundläggande antaganden. För det första antas en tilltro till massmedia föreligga om medborgarna uppfattar dess rapportering som rättvis. För det andra antas en misstro mot massmedia föreligga om medborgarna uppfattar dess rapportering som orättvis.

Det finns många argument för att undersöka medborgarnas subjektiva inställning till massmedias rapportering av politiska skandaler. För det första är politiska skandaler inte ovanliga (Bromander 2014). Med jämna mellanrum möter medborgaren skandaler genom massmedia. Alla partier drabbas av skandaler och händelserna passar väl det som kallas ”medielogiken”. För det andra är en av massme- 
dias demokratiska uppgifter att granska makt och makthavare. Rapportering av en skandal bör följa de krav som ställs på god journalistik. Om människor har en omotiverad hög misstro mot massmedierna så kan det innebära en försämring av den demokratiska kvalitén i ett samhälle. För det tredje för det inget gott med sig om medborgarna uppfattar att massmedia gör skillnad på kvinnor och män i rapporteringen av skandaler. I den bästa av alla världar är mediernas rapportering jämlik.

\section{Den politiska skandalens kännetecken}

Vad är en politisk skandal? Politiska skandaler har förekommit så länge som det har funnits politik. Ett inte allt för vågat antagande är därför att politiska skandaler också kommer att förekomma så länge som politik finns. Dock vet ingen med säkerhet när nästa skandal kommer att inträffa. Att definiera en politisk skandal är både lätt och svårt. Det är lätt därför att egentligen kan vad som helst bli till en skandal. Vilka händelser som är att betrakta som en skandal respektive en ickeskandal är högst subjektivt. Vad som upprör oss människor ligger således i betraktarens öga. I så måtto är det lätt att definiera en politisk skandal. Svårigheten är att precisera definitionen. I den teoretiska litteraturen finns det ett flertal definitioner som tar fasta på olika aspekter av begreppet. I John B. Thompsons (2000) uppmärksammade bok Political Scandal - power and visibility in the media age slår den brittiska sociologen fast vad som kan betraktas som en minimidefinition av en politisk skandal. Thompson menar att den politiska skandalen innehåller tre karaktärsdrag.

"Actions or events involving certain kinds of transgressions which becomes known to others and are sufficiently serious to elicit a public response" (Thompson 2000:13).

För det första kännetecknas skandalen av människans delaktighet genom att någon person bryter mot de värden, normer eller koder som är accepterade i ett samhälle. Varje skandal tar alltid sin början i att en eller flera personer har gjort sig skyldiga till en överträdelse av något slag. För det andra måste det finnas en kännedom om överträdelsen. Den politiska skandalen behöver vara känd bland allmänheten. Annars är det endast ett lik i garderoben. Kännedom om en överträdelse måste dock inte komma i direkt anslutning till händelsen. Tvärtom kan överträdelser vara mycket gamla när de uppdagas. För det tredje förutsätter den politiska skandalen 
någon form av upprördhet bland allmänheten. Skandalen kännetecknas av att människor blir negativt berörda av huvudpersonens agerande.

En annan aspekt som kan göra det svårt att definiera en skandal är den kulturella kontext som en överträdelse uppkommer i. Vad som uppfattas som en skandal i Sverige behöver inte vara en skandal i Frankrike och vad som uppfattas som en skandal i Storbritannien behöver inte vara en skandal i Tyskland. I Sverige finns exempelvis en stark förväntan på att politiska representanter skall göra rätt för sig, leva som de lär, föregå med gott exempel och att de inte skor sig på det allmänna (Jacobsson 2005:144). En person som bryter mot någon av dessa oskrivna normer och värden riskerar att hamna i en skandal. Det är också så att människors uppfattningar om vad som är ett acceptabelt eller oacceptabelt beteende står under ständig förändring. Ett beteende som idag skulle anses vara oacceptabelt kan tidigare i historien ha bedömts vara acceptabelt.

\section{Massmedias roll i demokratin}

Vilken är massmedias roll i demokratin. är de som vilka företag som helst? Svaret på frågan är både ja och nej. Sett utifrån ett företagsekonomiskt perspektiv är massmedias huvudsakliga uppgift att tjäna pengar och säkerställa vinst till aktieägarna. Trots detta lever medierna och demokratin på många sätt i ett ömsesidigt förhållande. Kommunikationsforskaren James W Carey (1999:51) beskriver denna symbios med: "Without journalism there is no democracy, but without democracy there is no journalism either".

I forskningslitteraturen framförs ofta att nyhetsmedierna har flera betydelsefulla uppgifter i samhället (Nord 2000:12; Nord och Strömbäck 2002:22). Ofta tillskrivs medierna två uppgiftsområden, informationsspridning och granskning (Asp 2007, 2006). Granskningsuppdraget syftar till att avslöja oegentligheter och missförhållanden (Asp 2007, 2006). Sett ur ett samhällsperspektiv är rapporteringen om eventuella politiska skandaler ett viktigt uppdrag för massmedierna i arbetet med att granska den politiska makten. Mediernas betydelse för demokratin har till och med bedömts vara så pass viktiga att statliga utredningar har tilldelat dem konkreta uppgifter (SOU 1975:78; SOU 1995:37). ${ }^{1}$ Den politiska journalistiken bidrar till att människor kan bilda en egen uppfattning om samhällsfrågor. Detta innebär i sin tur att samhället och dess medborgare kan ställa kvalitetskrav på den politiska journalistiken. Om det föreligger orättvisor i massmedias beskrivningar 
av politiker i skandaler så kan det i sin tur innebära att medborgarna får svårare att värdera informationen. Ett av huvudargumenten för att massmedia har en viktig roll i demokratin är dess unika ställning som informationskanal. Människor behöver nyhetsmedierna för att kunna ta del av politiska nyheter. Med detta beroendeförhållande tillkommer också ett ansvar för massmedia. Detta gäller inte minst i politiska skandaler där gestaltningen av en överträdelse kan få stor inverkan på hur människor uppfattar och bedömer händelsen. Nyhetsrapporteringen om en politisk skandal bör inte vara orättvis. Inte heller bör gestaltningen av skandalens huvudperson vara omotiverad eller irrelevant. För att medierna skall kunna uppfylla dessa krav förutsätts en nyhetsförmedling som är objektiv. Objektiviteten säkerställs genom en relevant och sanningsenlig rapportering men också genom att erbjuda nyhetskonsumenterna en balanserad och neutral rapportering (Westerståhl 1972:12ff).

\section{Människor behöver kunna känna förtroende för massmedia}

I vilken utsträckning har det betydelse om människor har förtroende för massmedia? Ett samhälle bygger på att människor i grund och botten har ett förtroende för dess samhällsinstitutioner (Holmberg och Weibull, 2013:225) Massmedia är inget undantag utan utgör en viktig samhällsfunktion. Ett demokratiskt samhälle är i behov av en förtroendeingivande nyhetsförmedling och politisk journalistik. Behovet av att få information om politik medför också att människor behöver kunna lita på nyhetsrapporteringen. Ett förtroende för massmedia skapas tills stor del av att nyhetsrapporteringen uppfattas som relevant och rättvis. Vid förekomsten av mediedrev riskerar exempelvis människors förtroende för massmedia som institution att försvagas.

Även om massmedia sällan utgör den enda informationskällan för människor så skall dess betydelse inte underskattas. Den person som söker efter information för att bilda sig en egen uppfattning om en skandal kommer med största sannolikhet att konsultera något av Sveriges största massmedier. I en politisk skandal är människor således i det närmaste helt beroende av massmedias nyhetsrapportering. Dock är det viktigt att inte glömma att medierna endast speglar en bild av verkligheten. 
Enligt MedieAkademins förtroendebarometer (2013) är svenskarnas förtroende för massmedia tudelat. Knappt varannan person (48 procent) anser sig ha mycket eller ganska stort förtroende för Radio och TV. Förtroendet för dagspressen är dock mera blygsamt. Endast var tredje svarsperson (29 procent) uppger sig ha mycket eller ganska stort förtroende. Bland dagspressen är det tabloidtidningarna som människor har lägst förtroende för. Endast tretton procent har mycket eller ganska stort förtroende för Aftonbladet. Motsvarande andel för Expressen var 10 procent. En uppfattning kan vara att kvällstidningar är att likställa med skvallertidningar. Trotts detta är det viktigt att understryka att såväl Aftonbladet som Expressen genom historien gjort många och viktiga avslöjanden av politiska missförhållanden. Mot bakgrund av människors allmänna förtroende för media som samhällsinstitution låt oss nu närmare analysera människors uppfattningar om massmedias rapportering av politiska skandaler.

\section{Stark misstro mot massmedias gestaltning av skandaler}

Ett av resultaten från Survey 2012 är att det finns en relativt stark misstro mot mediernas gestaltning av verkligheten i politiska skandaler. I tabell 1 presenteras fördelningen av respondenternas svar på de två påståenden som undersöks, "massmedia ger ofta en orättvis beskrivning av politiker som hamnar i skandaler" och ”kvinnor granskas hårdare än män i politiska skandaler”.

Som framgår av tabell 1 uttrycker knappt varannan respondent en misstro mot att massmedia ger en rättvis beskrivning av politiker som hamnar i skandaler. Endast var femte respondent anser att massmedias rapportering är rättvis. Att många människor uppfattar massmedia som orättvisa kan försvaga dess demokratiska legitimitet. I en förlängning kan det också innebära att människors förtroende för mediernas uppgift att granska makt och makthavare minskar ytterligare. Detta från en relativt låg nivå. 
Tabell 1. Svar på påståendet att "Massmedia ger ofta en orättvis beskrivning av politiker som hamnar i skandaler” samt påståendet Kvinnor granskas hårdare än män i politiska skandaler” Fördelat på respondentens kön.

\begin{tabular}{lccccc}
\hline & $\begin{array}{c}\text { Instämmer } \\
\text { helt eller } \\
\text { delvis }\end{array}$ & $\begin{array}{c}\text { Varken } \\
\text { eller }\end{array}$ & $\begin{array}{c}\text { Instämmer i } \\
\text { stort sett inte } \\
\text { eller inte alls }\end{array}$ & $\begin{array}{c}\text { Summa } \\
\text { procent }\end{array}$ & $\begin{array}{c}\text { Antal } \\
\text { svarande }\end{array}$ \\
\hline $\begin{array}{l}\text { Massmedia ger } \\
\text { ofta en orättvis } \\
\text { beskrivning av }\end{array}$ & & & & & \\
$\begin{array}{l}\text { politiker som } \\
\text { hamnar i } \\
\text { skandaler }\end{array}$ & 48 & 31 & 22 & 101 & 1514 \\
$\begin{array}{l}\text { Kvinnor granskas } \\
\text { hårdare än män i } \\
\text { politiska } \\
\text { skandaler }\end{array}$ & 48 & 32 & 20 & & \\
\hline
\end{tabular}

Misstron mot massmedia kvarstår också när en genusdimension inkluderas i det andra påståendet i tabell 1. När fokus skiftas från politiker som ett gemensamt kollektiv och istället indelas i två grupper framkommer att respondenter anser att kvinnor granskas hårdare än män. Sammanlagt 48 procent instämmer helt eller delvis i påståendet. Intressant är också att endast var femte respondent anser att massmedias rapportering är jämlik. Sett utifrån medborgarnas perspektiv finns här en stor förbättringspotential för massmedia.

Ur ett demokratiskt perspektiv kan resultaten från tabell 1 betraktas som relativt dystra. Men att misstro massmedia kan dock vara sunt. Problemet är att medborgarna i stor utsträckning är beroende av massmedias rapportering för att kunna bilda sig en uppfattning. I synnerhet gäller detta i skandaler. Vid en skandal är det få människor har tillgång till alternativ information.

Resultaten i tabell 1 ger inga indikationer på eventuella skillnader i attityder mellan grupper av människor. Därför är det av betydelse att ytterligare analysera respondenternas inställning till massmedia. Låt oss fördjupa analysen ytterligare genom att försöka urskilja några karaktärsdrag bland respondenterna i Survey 2012. Detta görs genom att analysera fyra möjliga skiljelinjer kön, ålder, politiskt intresse och politisk vänster-höger preferens. 


\section{Betydelse av respondentens kön}

Vilka eventuella likheter och skillnader kan finnas mellan kvinnor och män? I ett första steg analyseras datamaterialet utifrån respondenternas kön. I svaren på det genusneutrala påståendet "massmedia ger ofta en orättvis beskrivning av politiker som hamnar i skandaler” framkommer inga stora skillnader mellan kvinnor och män. I tabell 2 framgår att 46 procent av studiens kvinnor uppvisar en misstro genom att helt eller delvis instämma i påståendet. Motsvarande andel bland männen är 49 procent. Män och kvinnor uppfattar således mediernas rapportering om politiska skandaler på ett liknande sätt.

Tabell 2. Svar på påståendet att "Massmedia ger ofta en orättvis beskrivning av politiker som hamnar i skandaler” Fördelat på respondentens kön (procent).

\begin{tabular}{lccccc}
\hline & $\begin{array}{c}\text { Instämmer } \\
\text { helt eller } \\
\text { delvis }\end{array}$ & $\begin{array}{c}\text { Varken } \\
\text { eller }\end{array}$ & $\begin{array}{c}\text { Instämmer i } \\
\text { stort sett } \\
\text { inte eller } \\
\text { inte alls }\end{array}$ & $\begin{array}{c}\text { Summa } \\
\text { procent }\end{array}$ & $\begin{array}{c}\text { Antal } \\
\text { svarande }\end{array}$ \\
\hline Man & 49 & 27 & 24 & 101 & 742 \\
Kvinna & 46 & 34 & 20 & 100 & 772 \\
\hline Procentdifferens & 3 & -7 & 4 & & \\
\hline
\end{tabular}

Även om tabell 2 visar på respondenterna som en homogen grupp så finns det stora skillnader mellan könen i frågan om kvinnor och män granskas lika hårt av massmedia. Den tidigare homogena gruppen respondenter blir snabbt heterogen när en könsdimension inkluderas i analysen. En första och tydlig vattendelare är det egna könet. I tabell 3 framgår att kvinnor uppvisar en betydligt större misstro mot att massmedias rapportering av politiska skandaler är jämställd än vad män gör. 
Tabell 3. Svar på påståendet att "Kvinnor granskas hårdare än män i politiska skandaler” Fördelat på respondentens kön (procent)

\begin{tabular}{lccccc}
\hline & $\begin{array}{c}\text { Instäm- } \\
\text { mer helt } \\
\text { eller } \\
\text { delvis }\end{array}$ & $\begin{array}{c}\text { Varken } \\
\text { eller }\end{array}$ & $\begin{array}{c}\text { Instämmer i } \\
\text { stort sett } \\
\text { inte eller } \\
\text { inte alls }\end{array}$ & pumma & $\begin{array}{c}\text { Antal } \\
\text { sva- } \\
\text { rande }\end{array}$ \\
\hline Man & 37 & 34 & 30 & 101 & 741 \\
Kvinna & 59 & 30 & 11 & 100 & 774 \\
\hline Procentdifferens & -22 & 4 & 19 & & \\
\hline
\end{tabular}

Sammanlagt 59 procent av kvinnorna instämmer helt eller delvis i påståendet att "kvinnor granskas hårdare än män i politiska skandaler". Motsvarande andel bland männen är 37 procent. Könsdifferensen är 22 procentenheter. Det finns således ett samband mellan det egna könet och uppfattningen om huruvida det finns en dubbelstandard i hur massmedia rapporterar om kvinnor och män i politiska skandaler. Ett ytterligare exempel som illustrerar detta förhållande är att endast var tionde kvinna tar helt eller delvis avstånd från påståendet. Bland männen är knappt var tredje respondent av samma uppfattning. Männen som grupp, i tabell 3, är mera splittrad än kvinnorna. Det finns en tydlig uppfattning bland kvinnorna att massmedias rapportering inte är jämställd. Bland männen är den bilden långt ifrån lika tydlig.

\section{Betydelse av respondentens generationstillhörighet}

Hur människor uppfattar och värderar massmedia kan också påverkas av vilken tidsepok vederbörande är uppvuxen i. I tabell 4 har samtliga respondenter kategoriserats utifrån ålder. Uttrycket att vara "barn av sin tid” kan vara användbart då såväl massmedia som den politiska journalistiken och granskningen ständig utvecklas och förändras. Detta antagande till trots så har respondenternas generationstillhörighet en relativt liten betydelse för inställningen till massmedias beskrivningar av politiker som hamnar i skandaler. 
Tabell 4. Andelen respondenter som instämmer helt eller delvis i påståendena "massmedia ger ofta en orättvis beskrivning av politiker som hamnar i skandaler" efter generationstillhörighet (procent).

\begin{tabular}{lcccc}
\hline & $\begin{array}{c}\text { Förkrigs- } \\
\text { generationen } \\
(\mathbf{1 9 2 6 - 1 9 4 0 )}\end{array}$ & $\begin{array}{c}\text { Raket- } \\
\text { generationen } \\
(\mathbf{1 9 4 1 - 1 9 6 0 )}\end{array}$ & $\begin{array}{c}\text { Generation X } \\
\mathbf{( 1 9 6 1 - 1 9 8 0 )}\end{array}$ & $\begin{array}{c}\text { Generat- } \\
\text { ion M } \\
(\mathbf{1 9 8 1 -} \\
\mathbf{1 9 9 6 )}\end{array}$ \\
\hline $\begin{array}{l}\text { Massmedia ger ofta en orätt- } \\
\text { vis beskrivning av politiker }\end{array}$ & 53 & 44 & 17 & 53 \\
$\begin{array}{l}\text { som hamnar i skandaler } \\
\text { Kvinnor granskas hårdare än } \\
\text { män i politiska skandaler }\end{array}$ & 59 & 54 & 42 & 36 \\
\hline
\end{tabular}

Svaren på det genusneutrala påståendet visar att den generation som har störst misstro mot massmedia är förkrigsgenerationen. Störst tilltro har de människor som tillhör generation $\mathrm{X}$.

På frågan om kvinnor granskas hårdare än män går det att se skillnader mellan generationerna. Även om skillnaderna mellan de åldermässigt närstående generationerna inte är så stora så framgår i tabell 4 att äldre generationer uppvisar en större skepticism mot att massmedia förmedlar en jämställd nyhetsrapportering än yngre generationer. Det föreligger således en större misstro mot massmedia bland äldre än bland yngre. Differensen mellan den äldsta generationen (förkrigsgenerationen) och den yngsta generationen (generation $\mathrm{M}$ ) är 23 procentenheter. Bland dem som är födda mellan 1981-1996, och som ofta benämns som "generation M”, återfinns den största tilltron till att massmedia inte gör skillnad på kvinnor och män i deras nyhetsrapportering av skandaler.

\section{Betydelse av respondentens politiska intresse}

Människors attityder till massmedia kan också färgas av politiskt intresse. Rimligen har den som är intresserad av politik en större benägenhet att läsa politiska nyheter och följer möjligen också rapporteringen av politiska skandaler mer noggrant än de som har ett lägre intresse för politik.

I tabell 5 framgår att politiskt intresse har betydelse för inställning till massmedia. Svaren på det genusneutrala påståendet visar på en större misstro mot massmedia 
bland de som är intresserade av politik jämfört med människor som anser sig vara mindre intresserade av politik. Skillnaden i misstron till att massmedias inte ger en rättvis bild av kvinnor och män i skandaler, mellan de som är mycket intresserad av politik och de som inte alls är intresserad av politik, är 20 procentenheter.

Tabell 5. Svar på påståendet att "Massmedia ger ofta en orättvis beskrivning av politiker som hamnar i skandaler" efter politiskt intresse (procent).

\begin{tabular}{|c|c|c|c|c|c|}
\hline & \multicolumn{4}{|c|}{ Politiskt intresse } & \multirow[b]{2}{*}{ Samtliga } \\
\hline & $\begin{array}{c}\text { Mycket } \\
\text { intresserad }\end{array}$ & $\begin{array}{c}\text { Ganska } \\
\text { intresserad }\end{array}$ & $\begin{array}{c}\text { Inte särskilt } \\
\text { intresserad }\end{array}$ & $\begin{array}{c}\text { Inte alls } \\
\text { intresserad } \\
\end{array}$ & \\
\hline Instämmer helt & 58 & 49 & 46 & 38 & 48 \\
\hline $\begin{array}{l}\text { eller delvis } \\
\text { Varken eller }\end{array}$ & 15 & 28 & 35 & 43 & 31 \\
\hline $\begin{array}{l}\text { Instämmer i stort } \\
\text { sett inte eller in- } \\
\text { stämmer inte alls }\end{array}$ & 27 & 23 & 19 & 19 & 22 \\
\hline Summa procent & 100 & 100 & 100 & 100 & 101 \\
\hline Antal svarande & 160 & 658 & 527 & 166 & 1511 \\
\hline
\end{tabular}

Kommentar: Frågan om politiskt intresse löd ”Hur intresserad är du i allmänhet av politik?”.

Även när respondenterna ställs inför det genusmarkerade påståendet kvarstår sambandet mellan politiskt intresse och inställning till massmedia. Personer med ett stort politiskt intresse har en större misstro mot massmedia än personer med lågt politiskt intresse. I tabell 6 framgår att 54 procent av de som är mycket intresserade av politik anser att kvinnor granskas hårdare än män i politiska skandaler. Motsvarande andel bland de som inte alls är intresserade av politik är 38 procent. Differensen är 16 procentenheter. 
Tobias Bromander

Tabell 6. Svar på påståendet att "Kvinnor granskas hårdare än män i politiska skandaler" efter politiskt intresse (procent).

\begin{tabular}{lccccc}
\hline \multicolumn{6}{c}{ Politiskt intresse } \\
\hline & $\begin{array}{c}\text { Mycket } \\
\text { intresserad }\end{array}$ & $\begin{array}{c}\text { Ganska } \\
\text { intresserad }\end{array}$ & $\begin{array}{c}\text { Inte särskilt } \\
\text { intresserad }\end{array}$ & $\begin{array}{c}\text { Inte alls } \\
\text { intresserad }\end{array}$ & Samtliga \\
\hline $\begin{array}{l}\text { Instämmer } \\
\text { eller delvis }\end{array}$ & 54 & 50 & 46 & 38 & 47 \\
$\begin{array}{l}\text { Varken eller } \\
\begin{array}{l}\text { Instämmer i stort } \\
\text { sett inte eller in- } \\
\text { stämmer inte alls }\end{array}\end{array}$ & 21 & 29 & 35 & 48 & 33 \\
\hline Summa procent & $\mathbf{1 0 0}$ & $\mathbf{1 0 0}$ & $\mathbf{1 0 0}$ & $\mathbf{1 0 0}$ & $\mathbf{1 0 0}$ \\
\hline Antal svarande & $\mathbf{1 6 0}$ & $\mathbf{6 6 0}$ & $\mathbf{5 2 4}$ & $\mathbf{1 6 8}$ & $\mathbf{1 5 1 2}$ \\
\hline
\end{tabular}

Kommentar: Frågan om politiskt intresse löd "Hur intresserad är du i allmänhet av politik?”.

En viktig notering är att respondenternas svar på såväl det genusneutrala påståendet som det genusmarkerade påståendet visade på ett samband mellan politiskt intresse och misstro till massmedias rapportering om skandaler. Desto högre politiskt intresse medborgana har desto större misstro till att massmedias förmedlar en rättvis bild av en politisk skandal.

\section{Betydelse av respondentens ideologiska hemvist}

Den fjärde och avslutande analysen av respondenternas inställning till de två påståenden som

ingick i Survey 2012 utgår från väljarnas egna ideologiska hemvist. Var människor placerar sig på en vänster-högerskala i politiken kan bidra till att identifiera vilka personer som känner störst misstro mot massmedia. Resultaten i tabell 7 visar dock att så inte är fallet. Svaren på det genusneutrala påståendet visar inga substantiella skillnader mellan de som placerar sig klart till vänster eller något till vänster i politiken samt de som placerar sig klart till höger eller något till höger i politiken. Oavsett om människor placerar sig till höger eller till vänster i politiken så är misstron mot hur massmedia beskriver politiker i skandaler utbredd. Den 
Medborgares misstro till massmedias rapportering av politiska skandaler

grupp som uppvisar lägst misstro till massmedierna är de som placerar sig i mitten på vänster-högerskalan.

Tabell 7. Svar på påståendet att "Massmedia ger ofta en orättvis beskrivning av politiker som hamnar i skandaler" efter respondentens vänsterhögerposition (procent).

\begin{tabular}{lcccc}
\hline & \multicolumn{5}{c}{ Vänster-högerposition } \\
\hline & $\begin{array}{c}\text { Klart till vänster } \\
\text { eller något till } \\
\text { vänster }\end{array}$ & $\begin{array}{c}\text { Varken till } \\
\text { höger eller } \\
\text { vänster }\end{array}$ & $\begin{array}{c}\text { Klart till höger eller } \\
\text { något till höger }\end{array}$ & $\begin{array}{c}\text { Samt } \\
\text { liga } \\
\text { pro- }\end{array}$ \\
\hline $\begin{array}{l}\text { Instämmer } \\
\text { eller delvis }\end{array}$ & 50 & 40 & 50 & 47 \\
$\begin{array}{l}\text { Varken eller } \\
\begin{array}{l}\text { Instämmer i stort } \\
\text { sett inte eller in- } \\
\text { stämmer inte alls }\end{array}\end{array}$ & 22 & 39 & 28 & 32 \\
\hline Summa procent & $\mathbf{1 0 0}$ & $\mathbf{1 0 0}$ & 22 & 22 \\
\hline Antal svarande & $\mathbf{5 3 4}$ & $\mathbf{3 6 9}$ & $\mathbf{1 0 0}$ & $\mathbf{1 0 1}$ \\
\hline
\end{tabular}

Kommentar: Frågan om vänster-högerposition löd: "Man talar ibland om att politiska åsikter kan placeras in på en vänster-högerskala. Var skulle du placera dig själv på en sådan vänster-högerskala?”

Respondenternas ställningstagande till det genusmarkerade påståendet om att kvinnor granskas hårdare än män i politiska skandaler visar dock på en större spridning. I tabell 8 framgår att bland dem som anser sig vara klart till vänster eller något till vänster i politiken uttrycker 60 procent att kvinnor granskas hårdare än män. Motsvarande andel bland dem som anser sig vara klart till höger eller något till höger i politiken är andelen 40 procent. Differensen är 20 procentenheter. 
Tabell 8 Svar på påståendet: "Massmedia ger ofta en orättvis beskrivning av politiker som hamnar i skandaler" efter respondentens vänster-högerposition (procent).

\begin{tabular}{lcccc}
\hline & \multicolumn{5}{c}{ Vänster-högerposition } \\
\hline & $\begin{array}{c}\text { Klart till vänster } \\
\text { eller något till väns- } \\
\text { ter }\end{array}$ & $\begin{array}{c}\text { Varken till höger } \\
\text { eller vänster }\end{array}$ & $\begin{array}{c}\text { Klart till höger eller } \\
\text { något till höger }\end{array}$ & Samtliga \\
\hline $\begin{array}{l}\text { Instämmer } \\
\text { eller delvis } \\
\text { Varken eller }\end{array}$ & 60 & 43 & 40 & 48 \\
$\begin{array}{l}\text { Instämmer i stort } \\
\text { sett inte eller in- } \\
\text { stämmer inte alls }\end{array}$ & 25 & 39 & 32 & 32 \\
\hline Summa procent & 15 & 18 & 29 & 20 \\
\hline Antal svarande & $\mathbf{1 0 0}$ & $\mathbf{1 0 0}$ & $\mathbf{1 0 1}$ & $\mathbf{1 0 0}$ \\
\hline
\end{tabular}

Kommentar: Frågan om vänster-högerposition löd: "Man talar ibland om att politiska åsikter kan placeras in på en vänster-högerskala. Var skulle du placera dig själv på en sådan vänster-högerskala?”

Desto längre mot höger respondenterna placerar sig själva desto större tilltro finns till att massmedia inte gör skillnad på kvinnor och män i deras rapportering om politiska skandaler. Relationen är också tydlig mellan respondenternas partipreferenser (redovisas ej i någon tabell). Socialdemokraterna, Vänsterpartiet och Miljöpartiet är de partier vars sympatisörer som i störst utsträckning anser att rapporteringen om kvinnor och män är ojämlik.

\section{Avslutning}

Syftet i detta kapitel har varit att undersöka hur medborgarna uppfattar massmedias nyhetsrapportering om politiska skandaler. Finns det en samsyn bland medborgarna eller förekommer divergerande uppfattningar? Människors uppfattningar om massmedia har undersökts genom två enkätfrågor som formulerats som påståenden. 
1. Massmedia ger ofta en orättvis beskrivning av politiker som hamnar i skandaler

2. Kvinnor granskas hårdare än män i politiska skandaler

Utifrån Survey 2012 kan två resultat skönjas. Artikelns förta resultat är att det finns en stark misstro mot hur massmedia beskriver politiker som hamnar i skandaler. Oavsett om politikerna är kvinnor eller män anser 48 procent att massmedias rapportering är orättvis. Närmare analyser av svaren av påståendet "massmedia ger ofta en orättvis beskrivning av politiker som hamnar i skandaler" har visat på att medborgarna i stor utsträckning har samma uppfattning. Endast små eller mycket små skillnader i misstron mot massmedia kunde exempelvis påvisas mellan kvinnor och män. Samma mönster går igen vid beaktande av respondenterna ålder och människors egna politiska identifiering. Inga betydande skillnader har påvisats. Den enda betydande skillnaden som framkom i analyserna av det genusneutrala påståendet var att bland dem som anser sig vara mycket intresserad av politik är misstron mot massmedia starkare än bland dem som anser sig inte alls vara intresserad av politik. Skillnaden uppgick till 20 procentenheter.

Vad händer med människors attityder mot massmedia om respondenterna ombeds att ta ställning till en eventuell genusdimension i massmedias rapportering av skandaler? Artikelns andra resultat är att det finns en stark övertygelse bland respondenterna att kvinnor granskas hårdare än män i politiska skandaler. Sammanlagt 48 procent instämmer helt eller delvis i påståendet att "kvinnor granskas hårdare än män i politiska skandaler”. Endast 20 procent tar helt eller delvis avstånd från påståendet. Vid närmare analyser av det genusmarkerade påståendet framkom en mer heterogen bild av respondenterna i survey 2012. Analyserna påvisade flera betydande skillnader i attityden till en genusdimension i massmedia beroende på respondenternas kön, ålder, politiskt intresse eller politisk vänster-höger preferens.

- Kvinnor anser i större utsträckning än män att kvinnor granskas hårdare än män i politiska skandaler. 
- Människor som tillhör äldre generation anser i större utsträckning än de som tillhör yngre generationer att kvinnor granskas hårdare än män i politiska skandaler.

- Människor som är mycket intresserade av politik anser i större utsträckning än de som inte alls är intresserade av politik att kvinnor granskas hårdare än män i politiska skandaler.

- Människor som står till vänster i politiken anser i större utsträckning än dem som står till höger att kvinnor granskas hårdare än män i politiska skandaler.

Tabell 9. Sammanfattning av artikelns resultat (procentdifferens).

\begin{tabular}{|c|c|c|}
\hline Variabel & $\begin{array}{l}\text { Påstående } 1 \\
\text { Massmedia ger ofta en orättvis be- } \\
\text { skrivning av politiker som hamnar i } \\
\text { skandaler }\end{array}$ & $\begin{array}{c}\text { Påstående } 2 \\
\text { Kvinnor granskas hårdare än } \\
\text { män i politiska skandaler }\end{array}$ \\
\hline Kön & 3 & 22 \\
\hline Generation & 2 & 18 \\
\hline Politiskt intresse & 12 & 10 \\
\hline Ideologisk position & 0 & 20 \\
\hline
\end{tabular}

Kommentar: Procentdifferens för kön beräknas mellan kvinnor och män. Procentdifferens för generation beräknas mellan de respondenter som är födda 1926-1960 och de respondenter som är födda 1961-1996. Procentdifferens för politiskt intresse beräknas mellan de respondenter som uppger att de är mycket eller ganska intresserad av politik och de respondenter som uppger att de är ganska eller mycket ointresserad av politik. Procentdifferens för ideologisk position beräknas mellan de respondenter som uppger att de är klart till vänster eller något till vänster i politiken och de respondenter som uppger att de är klart till höger eller något till höger i politiken.

Inkorporerandet av en genusdimension i påståendet om massmedias nyhetsrapportering fick en effekt. Ett resultat från Survey 2012 är att beroende på kön, generation, politiskt intresse och ideologisk hemvist finns skillnader i uppfattningen om hur kvinnliga och manliga politiker behandlas i politiska skandaler. I tabell 9 
sammanfattas artikelns resultat genom att redovisa de procentuella skillnader som framkommit.

Tabell 9 visar på artikelns två huvudresultat. Med undantag för politiskt intresse är misstron mot massmedia inte särskilt polariserad när påståendet fokuserar på politiker generellt och där de är att betrakta som en gemensam grupp. Det är svårt att utkristallisera några karaktärsdrag bland dem som misstror massmediernas nyhetsrapportering. Endast mycket små skillnader finns bland kvinnor och män, äldre och yngre människor samt människor som placerar sig till vänster respektive höger i politiken.

Det framkommer dock en starkare polarisering av människors uppfattningar i frågan om en genusdimension i massmedias rapportering. Människors kön, deras ålder, intresse för politik och den ideologiska placeringen på vänster-högerskala har alla en stor betydelse för uppfattningen om jämställdheten i massmedias rapportering. Som tidigare understrukits är skillnader mellan olika grupper av respondenter små i resultaten från påstående 1. I resultaten från påstående 2 blir dock bilden den motsatta. När politiker som ett kollektiv delas upp i två grupper och ställs emot varandra framträder flera tydliga skillnader bland respondenterna.

En relevant fråga i sammanhanget är varför skillnader uppstår när en tydlig genusvärdering inkluderas i det andra påståendet i tabell 9. Även om utrymme inte ges för ett längre resonemang så är genus och en eventuell förekomst av könsstrukturer i samhället två frågor som står under ständig debatt. Debatterna präglas ofta av konflikt och konsensus saknas i sakfrågan. Betydelsen av genus i politiken utgör inget undantag. Mot bakgrund av en polariserad samhällsdebatt om genus är det inte ologiskt att det återfinns skiljelinjer i människors uppfattningar om huruvida kvinnor granskas hårdare än män i politiska skandaler. 


\section{Noter}

${ }^{1}$ Trots den samsyn som finns bland politiker, väljare och journalister kring medias uppgifter är det viktigt att understryka att dessa inte utgör något tvång (Hadenius och Weibull 2003). Uppgifterna utgör snarare ett eftersträvande massmedialt idealtillstånd (Strömbäck 2003).

\section{Referenser}

Allern, Sigurd och Pollack, Ester (2012): ’The Marketplace of Scandals”, i, Allern, Sigurd och Pollack, Ester (red). Scandalous! The Mediated Construction of Political Scandals in Four Nordic Countries. Göteborg: Nordicom.

Asp, Kent (2006): ”Mediernas uppgifter i valdemokratin”, i Bäck, Hanna och Gilljam, Mikael (red). Valets mekanismer. Malmö: Liber.

Asp, Kent (2007): Fairness, Informativeness and Scrutiny. The Role of News Media in Democracy. Nordicom Rewiev (28):31-49.

Bromander, Tobias (2012): Politiska Skandaler! Behandlas kvinnor och män olika i massmedia? Växjö: Linnaeus Univserity Press.

Carey, James W (1999): “In Defense of Public Journalism”, i Glasser, Theodore L. (red). The Idea of Public Journalism. New York: The Guilford Press.

Hadenius, Stig och Weibull, Lennart (2003): Massmedier: en bok om press, radio och TV. Stockholm: Bonnier.

Hagevi, Magnus (2014): ”Survey 2012: Teknisk rapport”, Surveyjournalen, 1 (1):59-67. Holmberg, Sören och Weibull, Lennart (2013): ’Det viktiga institutionsförtroendet”, i Weibull, Lennart, Oscarsson, Henrik och Bergström, Annika (red). Vägskäl. Göteborgs universitet: SOM-institutet.

Jacobsson, Kerstin och Sandstedt, Eva (2005): ”Upprördhet och moralisk ordning - om politikers lyxpensioner”, i Sjöstrand, Glenn (red). Fiffelsverige: sociologiska perspektiv på skandaler och fusk. Malmö: Liber

Jarlbro, Gunilla.(2009): ”Drevet mot Wanja värre för att hon är kvinna”, Newsmill. http://newsmill.se/artikel/2009/04/07/mediadrevet-mot-wanja-sexistiskt. Artikel publicerad 7 juli. 
Kleberg, Madeleine och Kristina Widestedt (2002): ’Ledare i blåsväder - mediernas privatisering av kvinnor”, i Hvitfelt, Håkan och Karvonen, Lauri (red). Den personliga politiken. Sundsvall: Demokratiinstitutet.

Kroon, Åsa (2007): ”Hur kunde du, Gudrun?”, i Ekström, Mats och Kroon, Åsa (red). Paketerad politik. elva essäer om journalistik och medier. Stockholm: Carlsson.

Nord, Lars och Strömbäck, Jesper (2002): Valfeber och nyhetsfrossa: politisk kommunikation i valrörelsen 2002. Stockholm: Institutet för mediestudier.

Nord, Lars (2000): Mediernas roller i demokratin. Rapport 1:2000. Stockholm: Institutet för mediestudier.

Romero, Mikael (2012): Tobleroneaffären: varför Sverige inte fick sin första kvinnliga statsminister. Stockholm: Norstedt.

Ronge, Paul (2012): ”Mediedrevet som fällde Håkan Juholt”. Paul Ronge Media AB. Internet: http://www.paulronge.se/mediedrevet-som-fallde-hakan-juholt, hämtat 21 januari 2013.

Sifo (2013): MedieAkademins förtroendebarometer.Uppsats. MedieAkademins seminarium på Mediedagarna i Göteborg (Meg) 7 mars 2013.

Strömbäck, Jesper (2003): Medierna som fjärde statsmakt: En studie av innebörden av begreppet granskande journalistik. Sundsvall: Demokratiinstitutet.

Thompson, John. B (2000): Political Scandal: Power and Visibility in the Media Age. Cambridge: Polity Press.

Westerståhl, Jörgen (1972): Objektiv Nyhetsförmedling. Göteborg: Akademiförlaget. 